\title{
Determination of dust and microorganism accumulation in different designs of AHU system in Shaanxi History Museum
}

\author{
Angui Li ${ }^{\mathrm{a}}$, Jing Xiong ${ }^{\mathrm{a}}$, Lingzhi Yao ${ }^{\mathrm{a}}$, Li Gou $^{\mathrm{a}}$, Wenrong Zhang ${ }^{\mathrm{a}}$
}

\begin{abstract}
Serial environmental measurements were conducted in the Shaanxi History Museum with two different air handling unit (AHU) designs to obtain a distribution of airborne and dust-borne microorganisms, and to determine the effects of occupant density, temperature and relative humidity $(\mathrm{RH})$ on airborne or dust-borne microbial counts.
\end{abstract} Samples were collected from five segments of three AHU systems during 9:00 10:00 and 15:00 16:00. The results indicated that a high density of occupants caused a serious accumulation of airborne bacteria and fungi regardless of whether the system was a constant air volume (CAV) or variable air volume (VAV) system. In both of the aforementioned systems, the same downward trend in airborne bacterial counts was observed, where the highest counts were found at the return air segment, followed by the filter and supply air segments. Nevertheless, airborne fungal counts showed opposing trends in CAV and VAV systems. Our results also demonstrated that dust loading in the VAV system was in the range of $1.1 \sim 13.3 \mathrm{~g} / \mathrm{m}^{2}$ which meets the Chinese standard, while dust-borne bacterial counts $\left(4.6 \times 10^{4} \sim 36.9 \times 10^{4} \mathrm{CFU} / \mathrm{g}_{\text {dust }}\right)$ and fungal counts $\left(5.3 \times 10^{4} \sim 1129 \times 10^{4} \mathrm{CFU} / \mathrm{g}_{\text {dust }}\right)$ far exceeded relevant threshold value. 
Furthermore, dust loading was more closely correlated with dust-borne bacteria levels than dust-borne fungi levels. In addition, airborne or dust-borne fungal counts were higher than the bacterial counts in the same sampling locations in the two systems. The predominant fungal genera that were consistently identified in different segments of both CAV and VAV systems were Penicillium, Aspergillus and Cladosporium. Moreover, RH exerted a greater influence on microbial growth than temperature.

Keywords: Air handling unit; Museum; Bacteria; Fungi; Dust loading

Corresponding author. No.13, YantaStreet, Beilin District, Xi'an, 710055, China. Tel/fax: +86 29 82205958. E-mail address: Liag@xauat.edu.cn (A. Li). 


\section{Introduction}

As the core components of air conditioning systems, AHU systems are extensively applied in public buildings to adjust indoor environmental parameters to satisfy comfort requirements of the occupants or special environments. They are not only sources of indoor cool or warm air but also contain many pollutants, which are mainly particles and microorganisms, including bacteria and fungi [1]-[9]. The deposition of particles causes serious dust loading and creates favorable living conditions for microbial growth, including a source of humidity, a suitable temperature and nutrients from dusts [9]-[11]. When the particles are re-suspended under sufficient kinetic energy [12], the hazardous materials may enter more rooms and expose more occupants through the intricate network of ducts often found in public buildings. Various studies have stated that air conditioning systems has responsibility on $50 \%$ 60\% of indoor air quality (IAQ) problems in building [13]-[15]. Occupants who spend many hours in buildings that have IAQ problems suffer from symptoms such as allergy, asthma, eye, nose and throat irritation, as well as cardiovascular problems [16]-[18]. Several respiratory illness in children are associated with a specific diameter range of cultivable fungi species [19]. To improve this situation and develop effective solutions, it is necessary to understand the distribution of dust and microorganisms in AHU systems.

Previous studies have focused on the following aspects: airflow patterns and particle dispersion[20], characteristics of particle deposition or re-suspension in a single unit [21]-[24] and microbial growth on the surface of ducts or single units [9]. 
Fine particles $\left(d_{\mathrm{p}}=1,10,30,50 \mu \mathrm{m}\right)$ are likely to follow the airflow while coarse particles $\left(d_{\mathrm{p}}=80,100 \mu \mathrm{m}\right)$ can be deposited and exhausted through the inlet bend [20]. The maximum particle count has previously been found to occur on the bottom of ducts and was two orders of magnitude higher than on other walls [25]. Bend segments as well as carina of bifurcation can easily become places of high particle accumulation. Furthermore, particle deposition is enhanced with increasing humidity from $66 \%$ to $95 \%$ [26]. Turbulent flows in ducts make particles deposit more easily [27]. When the inner-surface roughness of ducts increases, particle concentrations in the breathing area decrease, especially for fine particles [13]. This is due to the fact that the deposition velocity of particles increases along with an increase in inner-surface roughness [28]. As a result, more particles will be trapped in rougher ducts. Inevitably, the breathing area will be exposed to lower particle concentrations.

Airborne fungal species are distributed on different segments of air conditioning systems in complex fashion. Some fungi detected in the downstream areas are unable to be detected in upstream areas, indicating that there are breeding sources of these fungi [29]. Microorganisms breed easily on filters in a damp environment [30]. RH levels lower than $80 \%$ can effectively avoid microbial proliferation in ducts [31]. According to an investigation of 24 buildings in Beijing, bacterial and fungal loadings may exceed threshold values in heating and supply air segments, even if dust loading meets the relevant standards [32]. Microorganism counts are positively correlated with dust loadings. Dust that contains organisms is beneficial to microbial growth. When dust loading increases, microorganism counts also increase. The correlation 
coefficient between dust loading and bacteria is higher than that of fungi [33]. In terms of microbial species present in dust, Gram-positive bacteria $\left(\mathrm{G}^{+}\right)$account for $56 \%$ while Gram-negative bacteria $\left(\mathrm{G}^{-}\right)$account for $44 \%$ of the total bacteria in dust. The predominate fungi are Penicillium (32.5\%), Aspergillus (18.1\%), Cladosporium $(36.7 \%)[34]$

In the current study, we investigated several aspects that have been previously ignored: the influence of different AHU designs on the accumulation of dust and microorganisms, the distribution of dust loading and airborne or dust-borne microorganisms in an integral AHU system.

\section{Methods}

\subsection{Object details}

Field tests were conducted in a typical public building, Shaanxi History Museum, which is located northwest of the Big Wild Goose Pagoda in Xi'an, as shown in Fig. 1. Thirteen central air conditioning systems in the museum were classified into three groups based on their different functions: systems for the pavilion $(\mathrm{K} 1 \sim \mathrm{K} 6)$, systems for the storeroom (K9 K12), and systems for providing comfort (K7, K8, K13).

Among the 13 systems, three AHU systems were chosen to sample from: the K4 CAV system, the K4 VAV system and the K7 VAV system. The K4 CAV and K4 VAV systems have been running for many years while the K7 VAV system had only been operational for three months. All AHU systems run constantly throughout the year and were kept in normal operation during the sampling process. The three AHU systems were all primary return air systems with two fans and were covered by galvanized 
steel sheets, as shown in Fig. 2. Temperature \& humidity sensors were set at the return air segment. The operating parameters of the three AHU systems are shown in

Table 1. No occupants complained about the indoor air quality.

Table 1

Operating parameters of the three AHU systems.

\begin{tabular}{|c|c|c|c|}
\hline & K4 CAV system & K4 VAV system & K7 VAV system \\
\hline $\begin{array}{c}\text { Return air } \\
\text { segment }\end{array}$ & $\begin{array}{c}\mathrm{L}^{\mathrm{a}}=14208 \mathrm{~m}^{3} / \mathrm{h} \\
\mathrm{P}^{\mathrm{b}}=450 \mathrm{~Pa}\end{array}$ & $\begin{array}{c}\mathrm{L}^{\mathrm{a}}=21426 \mathrm{~m}^{3} / \mathrm{h} \\
\mathrm{P}^{\mathrm{b}}=450 \mathrm{~Pa}\end{array}$ & $\begin{array}{c}\mathrm{L}^{\mathrm{a}}=21209 \mathrm{~m}^{3} / \mathrm{h} \\
\mathrm{P}^{\mathrm{b}}=450 \mathrm{~Pa}\end{array}$ \\
\hline $\begin{array}{l}\text { Exhaust/return air } \\
\text { control segment }\end{array}$ & \multicolumn{3}{|c|}{ Electric chain of exhaust valve and control valve } \\
\hline Coarse filter & & Folded filter & \\
\hline $\begin{array}{l}\text { Humidifying } \\
\text { segment }\end{array}$ & $\mathrm{W}^{\mathrm{c}}=9 \mathrm{~kg} / \mathrm{h}$ & $\mathrm{W}^{\mathrm{c}}=13 \mathrm{~kg} / \mathrm{h}$ & $\mathrm{W}^{\mathrm{c}}=15 \mathrm{~kg} / \mathrm{h}$ \\
\hline Heating segment & $Q^{d}=9229 W$ & $Q^{d}=13456 W$ & $Q^{\mathrm{d}}=85838 \mathrm{~W}$ \\
\hline Cooling segment & $\mathrm{Q}=101126 \mathrm{~W}$ & $\mathrm{Q}=152502 \mathrm{~W}$ & $\mathrm{Q}=151190 \mathrm{~W}$ \\
\hline Supply air & $\mathrm{L}=14208 \mathrm{~m}^{3} / \mathrm{h}$ & $\mathrm{L}=21426 \mathrm{~m}^{3} / \mathrm{h}$ & $\mathrm{L}=21209 \mathrm{~m}^{3} / \mathrm{h}$ \\
\hline segment & $\mathrm{P}=850 \mathrm{~Pa}$ & $\mathrm{P}=850 \mathrm{~Pa}$ & $\mathrm{P}=850 \mathrm{~Pa}$ \\
\hline
\end{tabular}

${ }^{\mathrm{a}}$ Air volume, ${ }^{\mathrm{b}}$ Air pressure, ${ }^{\mathrm{c}}$ Additional moisture quantity, ${ }^{\mathrm{d}}$ Calefaction heat quantity.

\subsection{Sampling of airborne microorganism}

Nine tests for airborne microorganisms were conducted on the return air segment, filter segment, and supply air segment of the K4 CAV, K4 VAV and K7 VAV systems during 9:00 10:00 on December 18( $1^{\text {st }}$ day $)$, February 29(2 $2^{\text {nd }}$ day $)$ and March $11\left(3^{\text {rd }}\right.$ day). In order to observe the accumulation of airborne microorganisms, three tests for airborne microorganisms were conducted on each of the three segments of the K4 VAV and K7 VAV systems during 15:00 16:00 on February 29 (P.M.). There was no rain on the sampling days. The natural precipitation method was used to sample airborne microorganisms according to the Chinese standard [35]. The layout of sampling points in return air, filter and supply air segments is shown in Fig. 2, according to the British standard [36]. The sections were $\mathrm{A}_{1} \mathrm{~A}_{2} \mathrm{~A}_{3} \mathrm{~A}_{4}, \mathrm{~B}_{1} \mathrm{~B}_{2} \mathrm{~B}_{3} \mathrm{~B}_{4}$ and 
$\mathrm{E}_{1} \mathrm{E}_{2} \mathrm{E}_{3} \mathrm{E}_{4}$. Sterile glass plates (90 mm diameter) were filled with melting Beefprotein Dextrose Agar (BPDA) medium for sampling bacteria and Sabourand's Agar (SDA) medium for sampling .fungi, were placed at each sampling point for 5 minutes. The plates were tightly closed before and after sampling to decrease the risk of contamination.

\subsection{Sampling of dust and dust-borne microorganism}

Dusts in the K4 VAV and K7 VAV systems was sampled at the same time for airborne microorganisms. Dust was collected from the return air, filter, heating and supply air segments, as well as the filter screen. At the return air, filter and supply air segments, dust was sampled from the upper-wall, lower-wall and the two sidewalls. On each wall, five representative points covering an area of $50 \mathrm{~cm}^{2}$ were chosen as sampling points, according to the Chinese standard [35]. Finally, the average dust number of the five sampling points was calculated as dust loading. The filter screen and heating segment were sampled on the surface of the equipment. A detailed layout of the sampling points is shown in Fig. 2. The sections were $\mathrm{C}_{1} \mathrm{C}_{2} \mathrm{C}_{3} \mathrm{C}_{4}$ and $D_{1} D_{2} D_{3} D_{4}$. A sterilized non-woven fabric $(100 \mathrm{~mm} \times 100 \mathrm{~mm})$ was used to wipe the dust from each sampling point. The amount of dust was measured by an electronic balance with an accuracy of $0.0001 \mathrm{~g}$. The difference between the initial weight (weight of the non-woven fabric that had been dried in a dryer for $24 \mathrm{~h}$ ) and the final weight (total weight of the fabric and dust after four hours of drying) was used to give the residual dust weight. Dust loading was calculated by the following equation (1) [32]: 


$$
L_{\text {dust }}=\Delta M / S
$$

Where, $L_{\text {dust }}\left(\mathrm{g} / \mathrm{cm}^{2}\right)$ is the dust loading, $\triangle M(\mathrm{~g})$ is the difference between initial and final weight and $S\left(\mathrm{~cm}^{2}\right)$ is the sampling area of the surface.

\subsection{Cultivation of microorganism}

In general, microorganisms in atmosphere, including bacteria, fungi and viruses can also exist in air-conditioning systems. Until now, there has been no hygienic specification for viruses in central air conditioning ventilation systems in public buildings in China. Furthermore, a majority of studies regarding microorganisms in air conditioning systems have mainly focused on fungi and bacteria [6], [7], [9]. Therefore, only bacteria and fungi were cultured and identified in this study based on the Chinese standard [35]

In order to cultivate dust-borne microorganisms, a series of pretreatments were conducted. Dust samples were placed aseptically into $100 \mathrm{~mL}$ of $0.01 \%$ Tween-80 aqueous solution. The mixed solution was then diluted in a ten-fold dilution series. Each dilution containing microorganisms was inoculated separately onto an agar plate. Three replicates for each samples were set for both fungi and bacteria.

After pretreatment of the dust samples, microorganisms were cultivated in the same way. BPDA medium was used to culture bacteria at $37^{\circ} \mathrm{C}$ for $48 \mathrm{~h}$. SDA medium was used to culture fungi at $28^{\circ} \mathrm{C}$ for $72 \mathrm{~h}$. Control samples were also inoculated onto plates. Examples of cultures are shown in Fig. 3. In order to decrease errors, the final results were based on the mean value of three replicates. 


\subsection{Counting of microorganism}

The Omelianski equation was used to calculate the concentrations of airborne bacteria and fungi (equation (2)). The equation considers that the number of microorganisms depositing on agar with an area of $100 \mathrm{~cm}^{2}$ is the same as the number of microorganisms in a $10 \mathrm{~L}$ volume of air.

$$
C=1000 /(A / 100 \times t \times 10 / 5) \times N=1000 \times 50 N /(A \times t)
$$

Where, $C\left(\mathrm{CFU} / \mathrm{m}^{3}\right)$ is the concentration of airborne bacteria or airborne fungi, $A\left(\mathrm{~cm}^{2}\right)$ is the area of sampling, $t(\min )$ is exposure time and $N$ is the number of $\mathrm{CFU}$.

Dust-borne bacterial or fungal counts were expressed in two ways, as shown in equation (3) and (4) [32]:

$$
L_{\text {bacteria/fungi }}=N_{\text {bacteria/fungi }} \times 100 / S
$$

Where, $L_{\text {bacteria/fungi }}\left(\mathrm{CFU} / \mathrm{cm}^{2}\right)$ is the dust-borne bacterial or fungal count per square centimeter, $N_{\text {bacteria/fungi }}(\mathrm{CFU})$ is the number of colony forming units of bacteria or fungi and $S\left(\mathrm{~cm}^{2}\right)$ is the sampling area.

$\Phi_{\text {bacteria/fungi }}=L_{\text {bacteria/fungi }} / L_{\text {dust }}$

Where, $\Phi_{\text {bacteria/fungi }}\left(\mathrm{CFU} / \mathrm{g}_{\text {dust }}\right)$ is the dust-borne bacterial or fungal count per gram of dust.

\subsection{Assessment criteria}

According to the Chinese standard, the assessment criteria in terms of different projects are shown in Table 2.

Table 2

Assessment criteria of pollution level [35].

\begin{tabular}{ccccc}
\hline \multirow{2}{*}{ Project } & $\begin{array}{c}\text { Airborne bacteria or } \\
\text { fungi count in }\end{array}$ & $\begin{array}{c}\text { Dust-borne } \\
\text { bacteria or fungi }\end{array}$ & $\begin{array}{c}\text { Dust loading } \\
\text { of inner duct }\end{array}$ & $\begin{array}{c}\text { Dust-borne bacteria } \\
\text { or fungi of inner }\end{array}$ \\
\hline
\end{tabular}




\begin{tabular}{ccccc}
\hline & supply air & & duct \\
\hline $\begin{array}{c}\text { Threshold } \\
\text { value }\end{array}$ & $C \leq$ & $\varphi_{\text {bacteria/ fungi }} \leq$ & $L_{\text {dust }} \leq$ & $L_{\text {bacterialfungi }} \leq$ \\
& $500 \mathrm{CFU} / \mathrm{m}^{3}$ & $50000 \mathrm{CFU} / \mathrm{g}_{\text {dust }}$ & $20 \mathrm{~g} / \mathrm{m}^{2}$ & $100 \mathrm{CFU} / \mathrm{cm}^{2}$ \\
\hline
\end{tabular}

\subsection{Measurement of RH and temperature}

A TSI multi-channel portable tester, model $8386 \mathrm{~A}$, was used to measure

temperature, $\mathrm{RH}$ and air velocity at each sampling point, as well as outdoor

environment. The test range and precision of these three parameters are shown in

Table 3. Site characteristics of the sampling locations are shown in Table 4.

Table 3

Parameters of RH and temperature measurement instrument.

\begin{tabular}{ccccc}
\hline Measurement & Manufacturer & Model & Range & Accuracy \\
\hline Temperature & TSI & VELOCICALC Plus & $-10 \sim 60{ }^{\circ} \mathrm{C}$ & $\pm 0.3^{\circ} \mathrm{C}$ \\
RH & TSI & $0 \sim 95 \% \mathrm{RH}$ & $\pm 3 \% \mathrm{RH}$ \\
Air velocity & TSI & $8386 \mathrm{~A}$ & $0 \sim 50.00 \mathrm{~m} / \mathrm{s}$ & $\pm 0.015 \mathrm{~m} / \mathrm{s}$ \\
\hline
\end{tabular}

Table 4

Site characteristics of sampling locations.

\begin{tabular}{|c|c|c|c|c|c|c|c|c|c|c|}
\hline \multirow[b]{2}{*}{ Sampling sites } & \multirow[b]{2}{*}{ Time } & \multicolumn{3}{|c|}{ K4 CAV system } & \multicolumn{3}{|c|}{ K4 VAV system } & \multicolumn{3}{|c|}{ K7 VAV system } \\
\hline & & $\begin{array}{c}\mathrm{T} \\
\left({ }^{\circ} \mathrm{C}\right)\end{array}$ & $\begin{array}{l}\mathrm{RH} \\
(\%)\end{array}$ & $\begin{array}{c}\mathrm{V} \\
(\mathrm{m} / \mathrm{s})\end{array}$ & $\begin{array}{c}\mathrm{T} \\
\left({ }^{\circ} \mathrm{C}\right)\end{array}$ & $\begin{array}{l}\mathrm{RH} \\
(\%)\end{array}$ & $\begin{array}{c}\mathrm{V} \\
(\mathrm{m} / \mathrm{s})\end{array}$ & $\begin{array}{c}\mathrm{T} \\
\left({ }^{\circ} \mathrm{C}\right)\end{array}$ & $\begin{array}{l}\mathrm{RH} \\
(\%)\end{array}$ & $\begin{array}{c}\mathrm{V} \\
(\mathrm{m} / \mathrm{s})\end{array}$ \\
\hline \multirow{4}{*}{$\begin{array}{l}\text { Return air } \\
\text { segment }\end{array}$} & $1^{\text {st }}$ day & 16.2 & 48.3 & 4.40 & 16.1 & 48.4 & 4.83 & 17.1 & 44.6 & 5.20 \\
\hline & $2^{\text {nd }}$ day & 15.5 & 38.8 & 5.11 & 17.2 & 43.9 & 3.51 & 16.2 & 36.6 & 5.50 \\
\hline & $3^{\text {rd }}$ day & 17.2 & 46.9 & 5.51 & 17.2 & 44.6 & 3.62 & 18.8 & 45.2 & 4.80 \\
\hline & P.M. $^{\mathrm{a}}$ & 14.4 & 33.2 & 4.50 & 15.2 & 36.4 & 2.70 & - & - & - \\
\hline \multirow{4}{*}{ Filter segment } & $1^{\text {st }}$ day & 17.9 & 46.8 & 5.50 & 16.0 & 43.4 & 6.15 & 18.0 & 43.7 & 3.90 \\
\hline & $2^{\text {nd }}$ day & 17.3 & 36.3 & 4.15 & 17.6 & 42.5 & 6.53 & 16.6 & 35.0 & 2.60 \\
\hline & $3^{\text {rd }}$ day & 22.2 & 45.6 & 4.49 & 17.9 & 41.7 & 6.50 & 19.0 & 44.0 & 2.70 \\
\hline & P.M. $^{\mathrm{a}}$ & 15.6 & 31.5 & 3.40 & 16.0 & 34.1 & 8.50 & - & - & - \\
\hline \multirow{4}{*}{$\begin{array}{l}\text { Supply air } \\
\text { segment }\end{array}$} & $1^{\text {st }}$ day & 22.9 & 45.6 & 1.31 & 23.7 & 40.5 & 2.34 & 21.0 & 39.4 & 3.13 \\
\hline & $2^{\text {nd }}$ day & 21.2 & 34.7 & 1.10 & 19.5 & 38.0 & 2.41 & 19.0 & 34.1 & 2.10 \\
\hline & $3^{\text {rd }}$ day & 24.0 & 43.7 & 1.30 & 22.1 & 36.4 & 2.76 & 20.1 & 44.6 & 2.20 \\
\hline & P.M. $^{\mathrm{a}}$ & 16.2 & 26.0 & 2.10 & 19.0 & 27.5 & 3.34 & - & - & - \\
\hline Outdoor in A.M. ${ }^{b}$ & & 13.3 & 44.3 & 0.53 & 15.3 & 45.8 & 0.96 & 16.7 & 40.2 & 0.85 \\
\hline Outdoor in P.M. $^{c}$ & & 15.2 & 38.3 & 0.95 & 12.6 & 38.7 & 0.47 & - & - & - \\
\hline
\end{tabular}

${ }^{\mathrm{a}}$ 15:00 16:00 on February 29. ${ }^{\mathrm{b}}$ Outdoor environment during 9:00 10:00. ${ }^{\mathrm{c}}$ Outdoor environment during 15:00 16:00. 


\section{Results and discussion}

\subsection{Distribution of airborne microorganism}

The distribution of airborne microorganisms in different AHU systems, as well as the outdoor counts, is shown in Fig. $\mathbf{4 a}, \mathbf{4 b}, \mathbf{4 c}, \mathbf{4 d}$. Generally, airborne fungal counts in the AHU systems were higher than that of outdoor airborne fungi for a whole day. While airborne bacterial counts in the AHU systems were higher than that of outdoor airborne bacteria only during 15:00 16:00. During 9:00 10:00, the majority of the outdoor airborne bacterial counts were higher than in the AHU systems. Airborne bacterial counts showed a declining trend in the direction of airflow, while airborne fungal distributions are more complex. Airborne bacterial counts were lower than airborne fungal counts at the same sampling locations.

The average airborne microbial counts during 9:00 10:00 of the three sampling days in the return air, filter, and supply air segments in the K4 CAV, K4 VAV and K7 VAV systems are shown in Table 5. All three systems showed a declining trend in airborne bacterial counts. Confounding variables may play a role in this decrease. The $\mathrm{RH}$ in the three systems was in the range of $26.0 \%$ 48.4\%, which was much lower than the suitable $\mathrm{RH}$ of $80 \%$, as found by Pan et al. [37]. Low RH is adverse to bacterial growth. Some bacterial aerosols deposit on the surfaces of the units along with particle aerosols. The lack of nutrients in the air may also have contributed to the death of bacteria. Another reason is that bacterial aerosols were partly intercepted by the filter, which has also been mentioned by Möritz et al. [31].

\section{Table 5}

Average airborne bacterial counts during 9:00 10:00 of the three sampling days. 


\begin{tabular}{ccccccc}
\hline & \multicolumn{2}{c}{ K4 CAV system } & \multicolumn{2}{c}{ K4 VAV system } & \multicolumn{2}{c}{ K7 VAV system } \\
& $\begin{array}{c}\text { Fungi } \\
\left(\mathrm{CFU} / \mathrm{m}^{3}\right)\end{array}$ & $\begin{array}{c}\text { Bacteria } \\
\left(\mathrm{CFU} / \mathrm{m}^{3}\right)\end{array}$ & $\begin{array}{c}\text { Fungi } \\
\left(\mathrm{CFU} / \mathrm{m}^{3}\right)\end{array}$ & $\begin{array}{c}\text { Bacteria } \\
\left(\mathrm{CFU} / \mathrm{m}^{3}\right)\end{array}$ & $\begin{array}{c}\text { Fungi } \\
\left(\mathrm{CFU} / \mathrm{m}^{3}\right)\end{array}$ & $\begin{array}{c}\text { Bacteria } \\
\left(\mathrm{CFU} / \mathrm{m}^{3}\right)\end{array}$ \\
\hline Return air segment & 9342 & 3825 & 7545 & 3809 & 5171 & 4962 \\
Filter segment & 8751 & 2950 & 8068 & 2515 & 5658 & 2829 \\
Supply air segment & 5868 & 1991 & 11333 & 2268 & 9694 & 1520 \\
\hline
\end{tabular}

As shown in Table 5, for both of K4 and K7 VAV systems, the average airborne fungal counts increased and were higher in the supply air segment than in the return air segment. One reason is that fungal spores have higher viability than bacteria and proliferate more easily than bacteria in central air conditioning systems, as reported by Tan and Huang et al. [38], [39]. As a result, more fungi can enter the filtered airflow and cause a higher concentration of fungi in the supply air segment, similar to the results of Möritz et al. [31]. Moreover, airborne fungal counts showed a decreasing trend in the CAV system while an increasing trend in the VAV systems. This illustrates that air patterns have a significant influence on airborne fungi. Airborne fungal counts were higher than airborne bacterial counts by approximately 1 6.4 times.

During 15:00 16:00, the same trend was apparent, as shown in Fig. 4d. In the K4 CAV system, both airborne bacterial and fungal counts decreased. In the K4 VAV system, airborne bacterial counts decreased while airborne fungal counts increased. The average airborne bacterial and fungal counts of the K4 CAV and K4 VAV systems during 9:00 10:00 were $2894 \mathrm{CFU} / \mathrm{m}^{3}$ and $8485 \mathrm{CFU} / \mathrm{m}^{3}$, respectively. During 15:00 16:00, the average airborne bacterial and fungal counts from the K4 CAV and K4 VAV systems were $15205 \mathrm{CFU} / \mathrm{m}^{3}$ and $19567 \mathrm{CFU} / \mathrm{m}^{3}$, respectively. Therefore, airborne bacterial counts were almost 5 times higher in the afternoon and fungal counts were almost 2 times higher in the afternoon. According to Fig. $\mathbf{4 a}, \mathbf{4 b}, \mathbf{4 c}$, it 
can be observed that similar outdoor microbial counts make little difference on indoor microbial counts. However, indoor microbial counts may increase a lot under the influence of higher outdoor microbial counts, seen as Fig. 4d. The air containing more microorganisms entered indoor air through two ways. Large number of microorganisms have been carried in by an increased number of visitors. According to building statistics, the number of occupants in the afternoon was twice that in the morning, indicating that a high density of occupants caused serious accumulation of airborne bacteria and fungi regardless of whether a CAV or VAV system was involved. In addition, outdoor microorganisms may also have moved indoors through natural convection via an open door. The finding that occupants can carry many pathogenic microorganisms has also been noted by Pastuszka and Mui et al. [40], [41].The microbial counts from the K7 VAV system were lower than those from the K4 CAV and K4 VAV systems owing to shorter running time. Therefore, after continuous operation, AHU systems can accumulate a number of microorganisms.

Our research group has conducted a series of experiments in summer [42]. The return air segment had the highest level of pollution. In summer, the highest count of airborne bacteria was $11638 \mathrm{CFU} / \mathrm{m}^{3}$, and the lowest was $5189 \mathrm{CFU} / \mathrm{m}^{3}$. The highest count of airborne fungi was $17614 \mathrm{CFU} / \mathrm{m}^{3}$, and the lowest was $8335 \mathrm{CFU} / \mathrm{m}^{3}$. In winter, the highest count of airborne bacteria was $8017 \mathrm{CFU} / \mathrm{m}^{3}$, and the lowest was $1100 \mathrm{CFU} / \mathrm{m}^{3}$, while the highest count of airborne fungi was $13987 \mathrm{CFU} / \mathrm{m}^{3}$, and the lowest was $3144 \mathrm{CFU} / \mathrm{m}^{3}$. Therefore, the loading of airborne bacteria and fungi in winter was lower than in summer.

\subsection{Distribution of dust loading and dust-borne microorganisms}

While testing for airborne microorganisms, dust loading and dust-borne microorganisms were also tested in the K4 VAV and K7 VAV systems. The 
distribution of dust loading and dust-borne microorganisms in different systems is shown in Fig. 5a, 5b.

Among the two systems, all dust loadings were below the threshold value of $20 \mathrm{~g} / \mathrm{m}^{2}$, according to the Chinese standard [35]. In the K4 VAV system, the highest dust loading appeared in the supply air segment, followed by the filter segment, heating segment, filter screen, and return air segment, with values of 13.3, 12.7, 9.2, 7.6 and $5.6 \mathrm{~g} / \mathrm{m}^{2}$, respectively. The dust loadings in the K7 VAV system, compared to the K4 VAV system, were much lower owing to the fact that it was a new system. The dust loading in return air, filter and supply air segments were $3.1,1.1,2.3 \mathrm{~g} / \mathrm{m}^{2}$, respectively.

The threshold value for a microbial count per gram of dust is $5 \times 10^{4} \mathrm{CFU} / \mathrm{g}_{\text {dust }}$ according to Chinese standard [35]. From Fig. 5a, 5b, almost all the samples exceeded the threshold value. In the K4 VAV system, the dust-borne bacterial count was in the range of $2.2 \times 10^{4} \sim 21.6 \times 10^{4} \mathrm{CFU} / \mathrm{g}_{\mathrm{dust}}$, and the highest bacterial count was from the filter screen, which was 4 times of the threshold value. This further illustrates that bacteria can proliferate on the filter. The dust-borne fungal count was in the range of $62.4 \times 10^{4} \sim 1129 \times 10^{4} \mathrm{CFU} / \mathrm{g}_{\text {dust }}$, with the highest value identified in the heating segment, indicating that the heating coil fins were highly polluted. The dust-borne fungal count was higher than the dust-borne bacterial count from each sampling point. The count of dust-borne fungi was higher than the dust-borne bacterial count by around 4 200 times. In the K7 VAV system, the dust-borne bacterial counts in the return air, filter and supply air segments were $7.9 \times 10^{4}$, 
$12.4 \times 10^{4}$ and $16.1 \times 10^{4} \mathrm{CFU} / \mathrm{g}_{\text {dust }}$, respectively. The dust-borne fungal counts in the return air, filter and supply air segments were $20.1 \times 10^{4}, 28.7 \times 10^{4}$ and $36.1 \times 10^{4} \mathrm{CFU} / \mathrm{g}_{\text {dust }}$, respectively. The count of dust-borne fungi was higher than that for dust-borne bacteria by approximately 2.5 times on average. From the above mentioned data, it can be seen that the microbial counts may exceed the threshold value even if dust loading meets the criteria, which is similar to the results observed by Liu et al. [32].

Fig. 6 shows the relationship between dust loading and dust-borne microbial count per square centimeter of sampling area $\left(\mathrm{CFU} / \mathrm{cm}^{2}\right)$. It can be seen that both the dust-borne bacterial and fungal counts were positively correlated with dust loading in terms of sampling area. There is a good linear relationship between dust loading and dust-borne bacterial levels; however, this was not the case for dust-borne fungi. This conclusion is similar to the results of Li et al. [33]. Meanwhile, dust-borne fungal counts were still higher than dust-borne bacterial counts in the same sampling location. The threshold value for dust-borne bacteria or fungi per square centimeter is $100 \mathrm{CFU} / \mathrm{cm}^{2}$ according to the Chinese standard [35]. Dust-borne bacterial and fungal counts were in the range of $15.5 \sim 161 \mathrm{CFU} / \mathrm{cm}^{2}$ and $19.1 \sim 4194 \mathrm{CFU} / \mathrm{cm}^{2}$, respectively. It can be seen that almost all the dust-borne bacterial counts were below the threshold value except for one point, while several fungal counts were over the threshold. As a result, different assessment results could be observed due to different assessment criteria. For example, in the return air segment of the K7 VAV system, when the dust loading was $3.1 \mathrm{~g} / \mathrm{m}^{2}$, dust-borne bacterial and fungal counts per gram of dust were 
$7.9 \times 10^{4} \mathrm{CFU} / \mathrm{g}_{\text {dust }}$ and $20.1 \times 10^{4} \mathrm{CFU} / \mathrm{g}_{\text {dust }}$, respectively, both of which exceeded the threshold value of $5 \times 10^{4} \mathrm{CFU} / \mathrm{g}_{\text {dust. }}$. Nevertheless, their counts per square centimeter were $24.8 \mathrm{CFU} / \mathrm{cm}^{2}$ and $68 \mathrm{CFU} / \mathrm{cm}^{2}$ which were lower than the threshold value of $100 \mathrm{CFU} / \mathrm{cm}^{2}$. Therefore, different evaluation methods should be considered to form better criteria for assessing microorganism contamination of dust.

In summer, the average dust loading in the K4 VAV system was $8.66 \mathrm{~g} / \mathrm{m}^{2}$, and the average dust loading in the K7 VAV system was $1.83 \mathrm{~g} / \mathrm{m}^{2}$. Meanwhile, the count of dust-borne bacteria per square centimeter was in the range of $4.6 \sim 86.6 \mathrm{CFU} / \mathrm{cm}^{2}$ and that of dust-borne fungi was in the range of 8.60 82.0 CFU/ $\mathrm{cm}^{2}$. However, in winter, the dust loading in the K4 VAV and K7 VAV systems were $9.80 \mathrm{~g} / \mathrm{m}^{2}$ and 2.34 $\mathrm{g} / \mathrm{m}^{2}$, respectively, while dust-borne microbial counts in these two systems were in the range of 12.04 204.00 CFU/ $\mathrm{cm}^{2}, 26.00 ~ 35500 \mathrm{CFU} / \mathrm{cm}^{2}$, respectively. Compared with the data from summer, dust loading and dust-borne microorganisms were higher in winter.

\subsection{Species and distributions of fungi in AHU systems}

Based on the above analyses, the levels of fungi was so high that it was necessary to identify the fungal genera present. Fungi were identified according to their microscopic colonial morphology by using a fluorescence microscope (Olympus BX51). The detected fungi were from the genera Penicillium, Aspergillus, Cladosporium, Alternaria, Mucor, Trichoderma and other yeasts. Rhizopus and Fusarium were not detected. Considering the very low detection rate, yeasts was classified as other species. Morphological characteristics of the major six kinds of 
fungi are displayed in Fig. 7.

Airborne and dust-borne fungi in the AHU systems are shown in Fig. 8. In the progress of testing airborne fungi, twelve samples from the K4 CAV and K4 VAV systems and nine samples from the K7 VAV system were analyzed. There was significant overlap between the fungal genera detected in the three AHU systems or different segments of a single AHU system. The predominant fungi were Penicillium, Aspergillus and Cladosporium. Penicillium was the most predominant genus and accounted for $38 \%$ of the total fungal counts. Aspergillus and Cladosporium both accounted for approximately $20 \%$ each. The detection rates of the three genera were approximately $100 \%$. However, the detection rate of Alternaria, which accounted for over $3.52 \%$ of the total fungal counts, was $83.33 \%$.

In the progress of detecting dust-borne fungi, fifteen samples from the K4 VAV, and seven samples from the K7 VAV were analyzed. These two systems and even different segments in one system had showed consistency in the fungal genera observed. The predominant fungi were Cladosporium, Penicillium, Aspergillus and Alternaria. Detection rates of the first three genera were $100 \%$, while a detection rate for Alternaria was $83.33 \%$. However, the predominant genera in the two systems were slightly different. In the K4 VAV system, the concentrations of dust-borne fungi were in a declining order as follows: Cladosporium, Penicillium, Aspergillus and Alternaria. The predominant genus was Cladosporium which accounted up for $64.12 \%$ of the total fungi. The order from high to low (in terms of fungal counts) in the K7 VAV system was Penicillium, Aspergillus, Cladosporium and Alternaria, and 
predominant genus was Cladosporium which accounted up for $45.41 \%$ of the total fungi.

The same predominant fungal genera in air and dust indicate a close relationship between them. Along with the deposition of particles, fungi in the air are the main source of dust-borne fungi. After depositing on the surface of units, fungi reproduce under suitable conditions. As a result, the airborne and dust-borne fungal genera were consistent. However, different environmental conditions will give rise to differing fungal counts in different segments.

Comparing to the winter and summer results shows that the same fungal genera were detected. There were some differences in the percentage of Cladosporium and Penicillium, where in summer, they accounted for $41.8 \%$ and $30.1 \%$, respectively, and in winter they accounted for $23.5 \%$ and $34.3 \%$, respectively of the total fungal counts.

\subsection{Influence of temperature and RH to microorganism}

The influence of temperature (T) and $\mathrm{RH}$ on the airborne microbial counts in the K4 CAV, K4 VAV and K7 VAV systems are shown in Fig. 9. Temperature ranged between $15.2^{\circ} \mathrm{C} \sim 24.0^{\circ} \mathrm{C}$, while $\mathrm{RH}$ ranged between $34.1 \% \sim 48.4 \%$. It was found that microbial counts increased when RH and temperature also increased. However, when temperature decreased while RH increased, microbial counts still increased. This suggests that RH exerted more influence than temperature on airborne microbial counts, which is in accordance with the results of Mui et al. [41]. Moreover, RH was in the range of $34.1 \sim 48.4 \%$ during the sampling time, which was more beneficial to 
the growth of fungi than bacteria, as pointed out by Mui et al. [41]. Harrmanm and Chen et al. [43], [44] also found that bacteria can be controlled when RH is in the range of 30\% 60\% while fungi, especially mucedine fungi, can grow well when $\mathrm{RH}$ is over $20 \%$. This further explains why the airborne and dust-borne fungal counts were higher than those for bacteria in our experiment. It was also observed that microorganisms grew rapidly from $44 \% \mathrm{RH}$ to $48.4 \% \mathrm{RH}$, including in the range of 40 90\% RH which was found by Li et al. [34].

\section{Conclusion}

The distribution of dust loading, and airborne and dust-borne microorganisms in different AHU designs in a museum was analyzed and the following conclusions could be drawn:

(1) It was found that regardless of whether there was a CAV or VAV system, the distribution of airborne bacteria was similar, namely, the highest bacterial count was found in the return air segment (3809 4962 CFU/ $\left.\mathrm{m}^{3}\right)$, followed by the filter segment $\left(2515 \sim 2950 \mathrm{CFU} / \mathrm{m}^{3}\right)$, and the supply air segment (1520 2268 $\left.\mathrm{CFU} / \mathrm{m}^{3}\right)$.

(2) Airborne fungi were influenced by different AHU operation conditions. In the CAV system, the distribution of airborne fungi showed the same trend as airborne bacteria. In the VAV system, the highest count of airborne fungi was in the supply air segment $\left(9694 \sim 11333 \mathrm{CFU} / \mathrm{m}^{3}\right)$, followed by the filter segment (5658 8068 $\left.\mathrm{CFU} / \mathrm{m}^{3}\right)$ and the return air segment $\left(5171 \sim 7545 \mathrm{CFU} / \mathrm{m}^{3}\right)$. This illustrates that variable airflow may accelerate the growth of fungi. 
(3) In AHU systems, bacterial counts were much lower than fungal counts at the same sampling points. Airborne fungal counts were higher than airborne bacterial counts by approximately 1 6.4 times. The count of dust-borne fungi per gram of dust was higher than for dust-borne bacteria by approximately $2.5 \sim 200$ times. However, the count of dust-borne fungi per square centimeter was higher than that of dust-borne bacteria by approximately 1 100 times.

(4) The fungal genera were remarkably consistent among different systems or different segments in one system. The predominant genera were Penicillium, Aspergillus and Cladosporium. RH exerted more influence than temperature on airborne microbial counts. It was also observed that $34.1 \sim 48.4 \% \mathrm{RH}$ was more beneficial for the growth of fungi than bacteria.

\section{Acknowledgements}

This study was supported by National Science Foundation of China, No. 50878177 and No. 50478046.

\section{References}

[1] P. J. Irga, F. R. Torpy, Indoor air pollutants in occupational buildings in a sub-tropical climate: Comparison among ventilation types, Build. Environ. 98 (2016) 190-199.

[2] A. J. Hoisington, J. P. Maestre, M. D. King, J. A. Siegel, K. A. Kinney, Impact of sampler selection on the characterization of the indoor microbiome via high-throughput sequencing, Build. Environ. 80 (2014) 274-282.

[3] J. C. S. Chang, K. K. Foarde, D. W. VanOsdell, Assessment of fungal 
(Penicillium chrysogenum) growth on three HVAC duct materials, Environ. Int. 22 (1996) 425-431.

[4] Z. Lu, W. Z. Lu, J. L. Zhang, D. X. Sun, Microorganisms and particles in AHU systems: Measurement and analysis, Build. Environ. 44 (2009) 694-698.

[5] T. Ramos, B. Stephens, Tools to improve built environment data collection for indoor microbial ecology investigations, Build. Environ. 81 (2014) 243-257.

[6] C. H. Tseng, H. C. Wang, N. Y. Xiao, Y. M. Chang, Examining the feasibility of prediction models by monitoring data and management data for bioaerosols inside office buildings, Build. Environ. 46 (2011) 2578-2589.

[7] P. C. Wu, Y. Y. Li, C. M. Chiang, C. Y. Huang, C. C. Lee, F. C. Li, H. J. Su, Changing microbial concentrations are associated with ventilation performance in Taiwan's air-conditioned office buildings, Indoor Air 15 (2005) 19-26.

[8] Z. Liu, W. Xu, C. Qian, X. Chen, and G. Jin, Investigation on the feasibility and performance of ground source heat pump (GSHP) in three cities in cold climate zone, China, Renew. Energy 84 (2015) 89-96.

[9] S. Pigeot-Remy, J. C. Lazzaroni, F. Simonet, P. Petinga, C. Vallet, P. Petit, P. J. Vialle, C. Guillard, Survival of bioaerosols in HVAC system photocatalytic filters, Appl. Catal. B Environ. 144 (2014) 654-664.

[10] K. Radon, B. Danuser, M. Iversen, E. Monso, C. Weber, J. Hartung, K. J. Donham, U. Palmgren, D. Nowak, Air contaminants in different European farming environments, Ann. Agric. Environ. Med. 9 (2002) 41-48.

[11] A. A. Hameed, M. I. Khodr, Suspended particulates and bioaerosols emitted 
from an agricultural non-point source, J. Environ. Monit. 3 (2001) 206-209.

[12] A. Li, X. Chen, C. Gu, R. Gao, Z. Hu, Prediction of particle deposition in rectangular ventilation ducts, Int. J. Vent. 11 (2012) 69-78.

[13] B. Zhao, J. Wu, Particulate pollution in ventilated space: Analysis of influencing factors, J. Hazard. Mater. 163 (2009) 454-462.

[14] R. A. Khan, K. D. Rao, Impact of HVAC systems on IAQ in building environment, IJARSE. 3 (2014) 184-192.

[15] R. Sulaiman, S. N. Kamaruzzaman, Visitors' perceptive agent ( VPA ) on museum indoor environment, HKICSS-112, (2012) 14-29.

[16] E. Sterling, C. Collett, S. Turner, C. Downing, Commissioning to avoid indoor air quality problems, ASHRAE Trans. 99 (1993) 1993.

[17] M.R. Sippola, W.W. Nazaroff, Modeling particle deposition in ventilation ducts, P. Indoor Air, (2002) 515-520.

[18] M. I. Gilmour, M. S. Jaakkola, S. J. London, A. E. Nel, C. A. Rogers, How exposure to environmental tobacco smoke, outdoor air pollutants, and increased pollen burdens influences the incidence of asthma, Environ. Health Persp. 114 (2006) 627-633.

[19] Z. Liu, A. Li, Z. Hu, H. Sun, Study on the potential relationships between indoor culturable fungi, particle load and children respiratory health in Xi'an, China, Build. Environ. 80 (2014) 105-114.

[20] N. L. Phuong, K. Ito, Experimental and numerical study of airflow pattern and particle dispersion in a vertical ventilation duct, Build. Environ. 59 (2013) 
466-481.

[21] R. Gao, A. Li, Dust deposition in ventilation and air-conditioning duct bend flows, Energy Convers. Manag. 55 (2012) 49-59.

[22] R. Gao, A. Li, Modeling deposition of particles in vertical square ventilation duct flows, Build. Environ. 46 (2011) 245-252.

[23] J. Zhang, A. Li, CFD simulation of particle deposition in a horizontal turbulent duct flow, Chem. Eng. Res. Des. 86 (2008) 95-106.

[24] J. Zhang, A. Li, Study on particle deposition in vertical square ventilation duct flows by different models, Energy Convers. Manag. 49 (2008) 1008-1018.

[25] B. Zhao,J. Chen, Numerical analysis of particle deposition in ventilation duct, Build. Environ. 41 (2006) 710-718.

[26] A. F. Miguel, A. H. Reis, M. Aydin, Aerosol particle deposition and distribution in bifurcating ventilation ducts, J. Hazard. Mater. 116 (2004) 249-255.

[27] H. Jiang, L. Lu, K. Sun, Simulation of particle deposition in ventilation duct with a particle-wall impact model, Build. Environ. 45 (2010) 1184-1191.

[28] B. Zhao, J. Wu, Modeling particle deposition onto rough walls in ventilation duct, Atmos. Environ. 40 (2006) 6918-6927.

[29] P. C. Kemp, H. G. Neumeister-Kemp, B. Esposito, G. Lysek, F. Murray, Changes in airborne fungi from the outdoors to indoor air; Large HVAC systems in nonproblem buildings in two different climates, AIHAJ. 64 (2003) 269-275. 
[30] F. Noris, J. A. Siegel, K. A. Kinney, Biological and metal contaminants in HVAC filter dust, ASHRAE Trans. 115 (2009) 484-491.

[31] M. Möritz, H. Peters, B. Nipko, H. Rüden, Capability of air filters to retain airborne bacteria and molds in heating, ventilating and air-conditioning (HVAC) systems. Int. J. Hyg. Environ. Health, 203 (2001) 401-409.

[32] Z. Liu, Z. Zhu, Y. Zhu, W. Xu, H. Li, Investigation of dust loading and culturable microorganisms of HVAC systems in 24 office buildings in Beijing, Energy Build. 103 (2015) 166-174.

[33] A. Li, Z. Liu, Y. Liu, X. Xu, Y. Pu, Experimental study on microorganism ecological distribution and contamination mechanism in supply air ducts, Energy Build., 47 (2012) 497-505.

[34] A. Li, Z. Liu, X. Zhu, Y. Liu, Q. Wang, The effect of air-conditioning parameters and deposition dust on microbial growth in supply air ducts, Energy Build. 42 (2010) 449-454.

[35] Ministry of Health of the People's Republic of China, WS 394-2012, Hygienic specification of central air conditioning ventilation system in public buildings, Beijing, 2012.

[36] BSI Standards Publication, Field testing of general ventilation filtration devices and systems for in situ removal efficiency by particle size and resistance to airflow, 2013.

[37] P. Pan, K. Deng, F. Guan, L. Ding, Microbial species analysis and temperature and humidity control in air conditioning system, Environ. Sci. Technol. 37 
(2014) 85-89. (in Chinese)

[38] D. Tan, C. Wu, Z. Zhan, S. Li, T. Huang, L. Wang, J. Liu, Study on health situation of ducts of central air conditioning systems in public buildings, Hunan Province, Pract. Prev. Medicine 12 (2005) 898-899. (in Chinese)

[39] Y. Huang, Y. Li, H. Yang, Y. Wang, Z. Li, J. Fang, Analysis of pollutions of central air conditioning ventilation systems in public buildings, Guangxi Province, Guangxi J. Prev. Medicine 11 (2005) 363-364. (in Chinese)

[40] J. S. Pastuszka, U. K. T. Paw, D. O. Lis, A. Wlazlo, K. Ulfig, Bacterial and fungal aerosol in indoor environment in Upper Silesia, Poland, Atoms. Environ. 34 (2000) 3833-3842.

[41] K. W. Mui, L. T. Wong, P. S. Hui, Risks of unsatisfactory airborne bacteria level in air-conditioned offices of subtropical climates, Build. Environ. 43 (2008) 475-479.

[42] A. G. Li, J. J. Hou, Z. B. Ji, and X. B. Zhu, A Case Study Distribution of Bacterial and Fungal Aerosols in Air-Conditioning Systems in Shaanxi History Museum, J. Hunan Univ. Sci. 36 (2009) 10-14.

[43] L. Harrmanm, G.W. Brundrett, R. Kittler, Humidity Control Design Guide for Commerical and Institutional Buildings, ASHRAE, 2001.

[44] W. Chen, M. He, A Case Study of Control Strategies and Contamination Routes of Indoor Moulds for the Hotel of Philippines, Acta Sci. Natur. Univ. Sunyatseni 42 (2003) 109-203.

\section{Figure Captions}


Fig. 1. Shaanxi History Museum, the sites investigated in the research, located in urban area of Xi'an city.

Fig. 2. Schematic of sampling points in AHU system. Sections of sampling airborne microbes: $A_{1}$ $A_{2} A_{3} A_{4}, B_{1} B_{2} B_{3} B_{4}, E_{1} E_{2} E_{3} E_{4}$; Sections of sampling dust and dust-borne microbes: $C_{1} C_{2} C_{3}$ $\mathrm{C}_{4}, \mathrm{D}_{1} \mathrm{D}_{2} \mathrm{D}_{3} \mathrm{D}_{4}$

Fig. 3 Real samples of microorganism.

Fig. 4 Distribution of airborne microorganisms in different AHU systems.

Fig. 5 Distribution of dust loading and dust-borne microorganisms in different systems.

Fig. 6. Relationship between dust-borne microbial counts and dust loading in term of sampling area.

Fig. 7. Morphological characteristics of six kinds of predominant fungi.

Fig. 8. Airborne and dust-borne fungi in AHU systems.

Fig. 9 Influence of temperature and RH to airborne microbial counts. 
Graphical Abstract

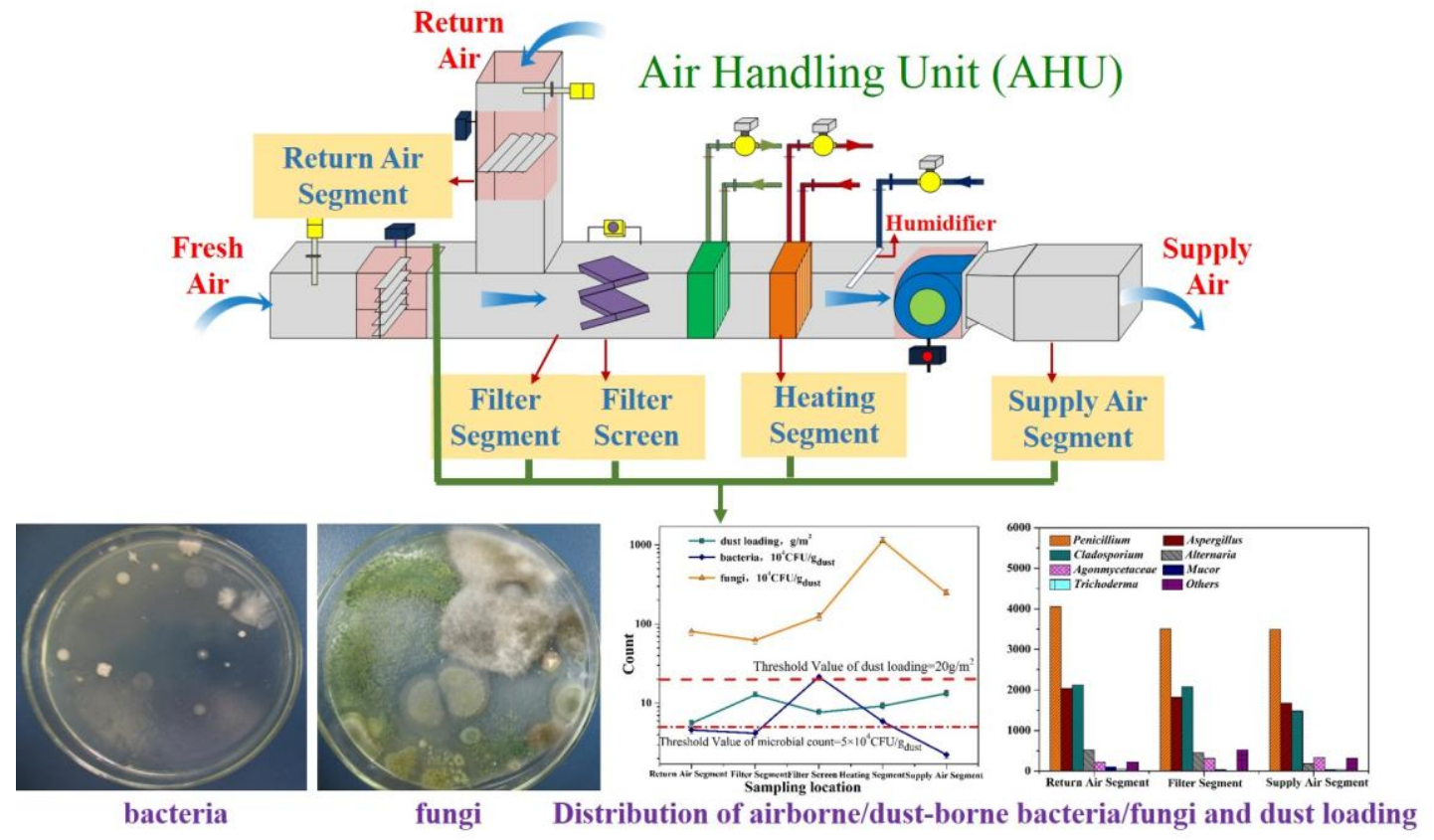




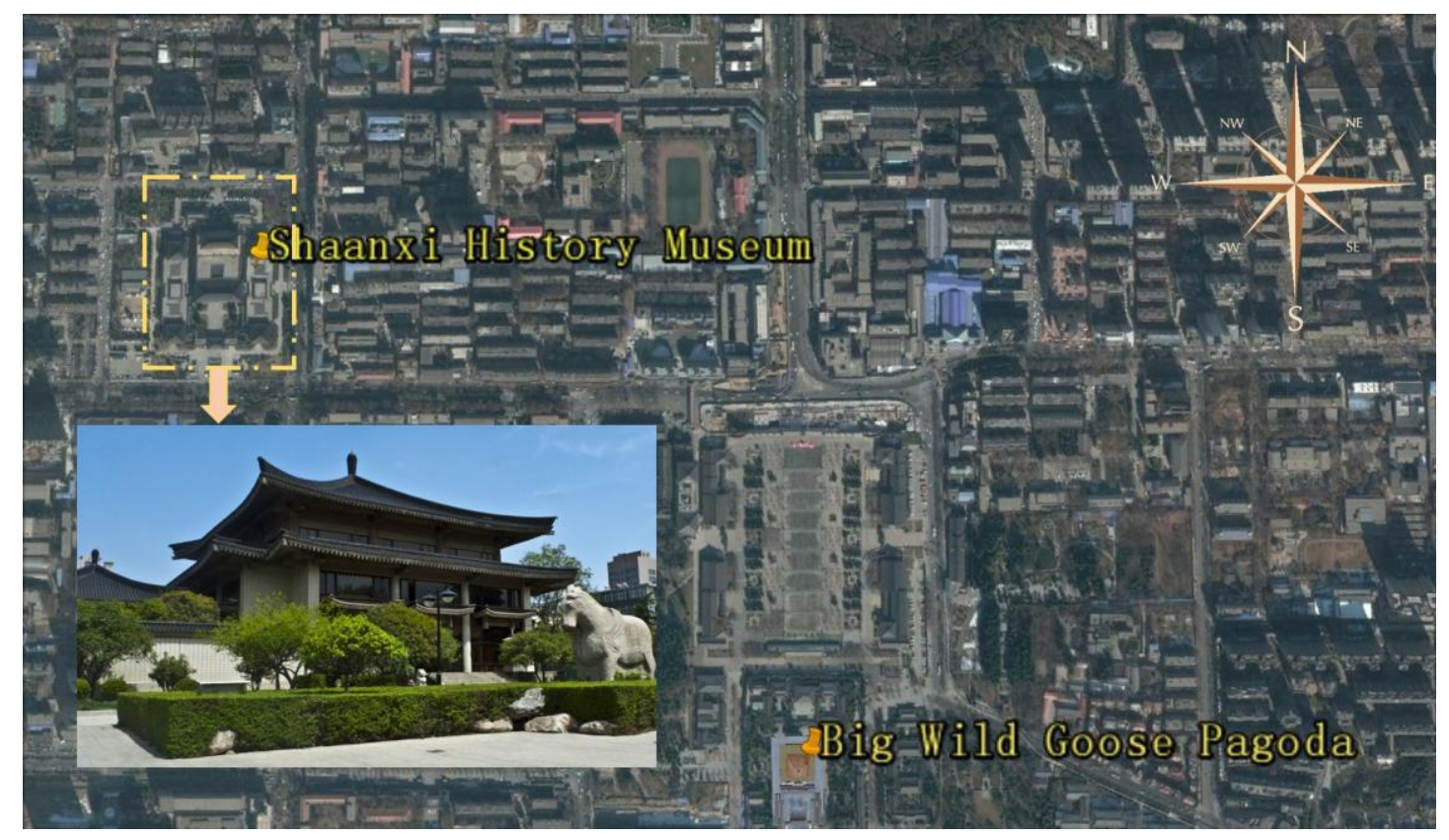

Fig. 1. Shaanxi History Museum, the sites investigated in the research, located in urban area of

Xi'an city.

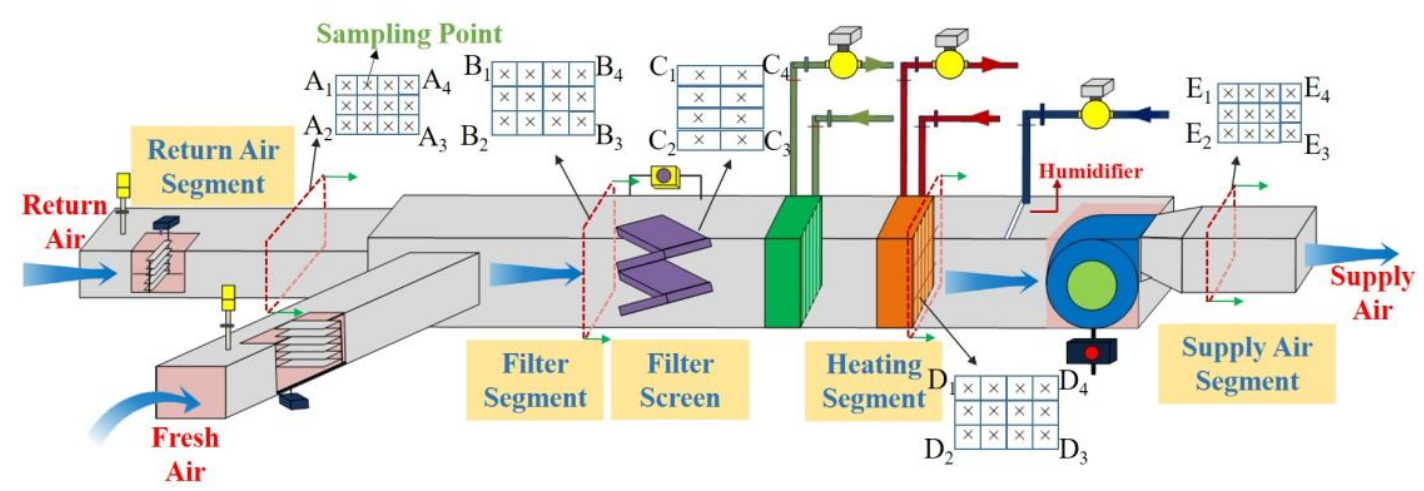

Fig. 2. Schematic of sampling points in AHU system. Sections of sampling airborne microbes: $A_{1}$

$A_{2} A_{3} A_{4}, B_{1} B_{2} B_{3} B_{4}, E_{1} E_{2} E_{3} E_{4}$; Sections of sampling dust and dust-borne microbes: $C_{1} C_{2} C_{3}$

$\mathrm{C}_{4}, \mathrm{D}_{1} \mathrm{D}_{2} \mathrm{D}_{3} \mathrm{D}_{4}$ 

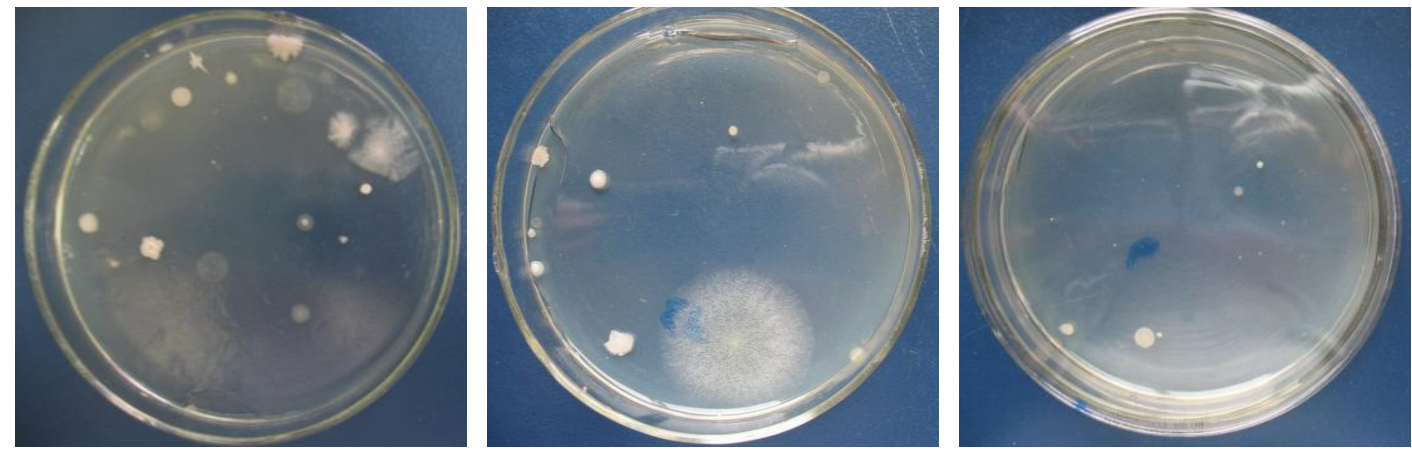

(a) Bacteria
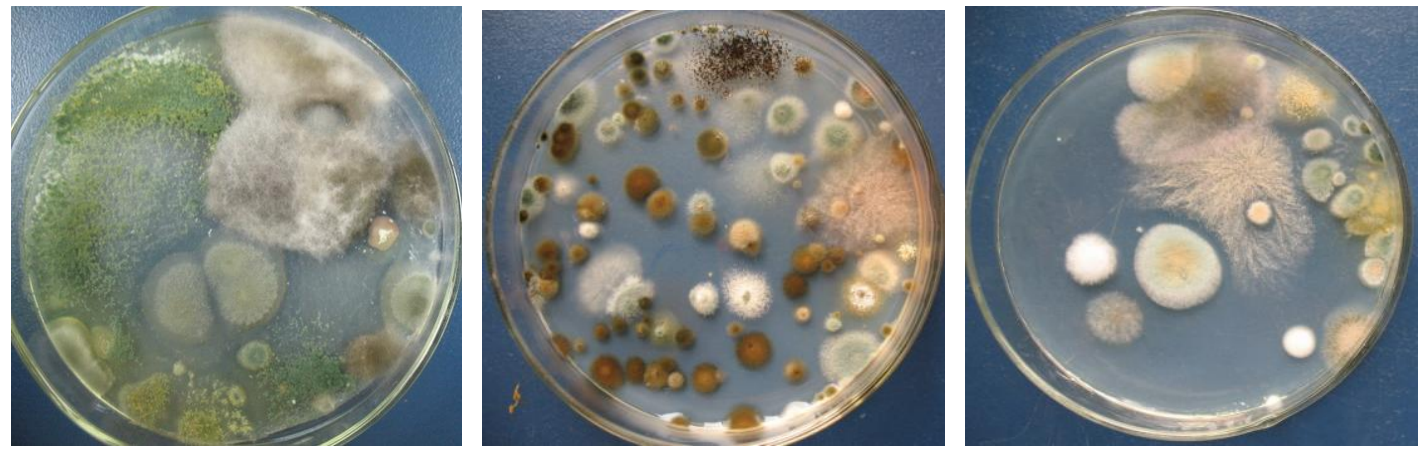

(b) Fungi

Fig. 3 Real samples of microorganism. 


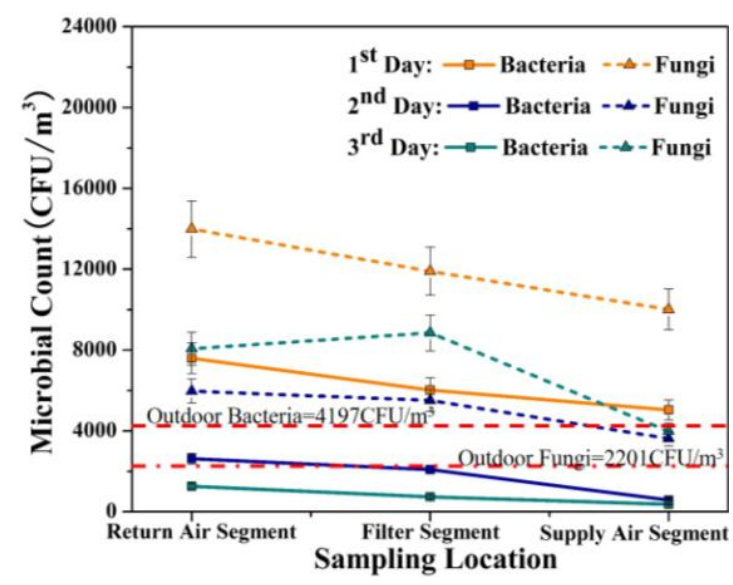

(a) K4 CAV system, 9:00 10:00

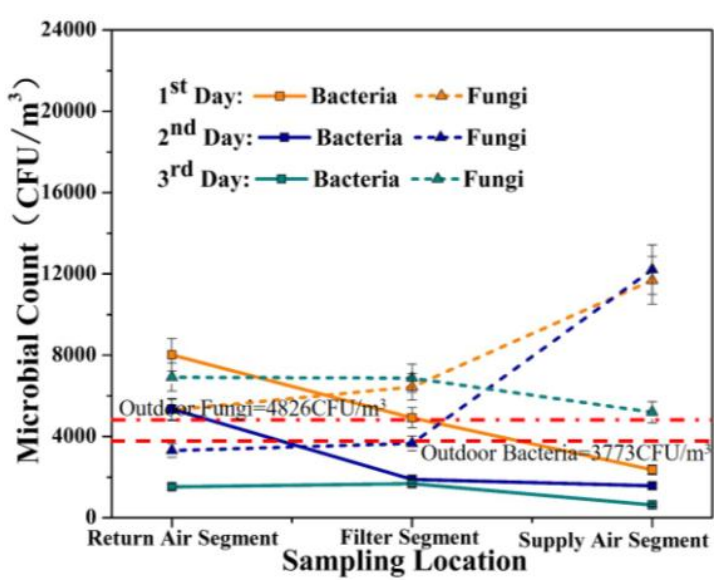

(c) K7 VAV system, 9:00 10:00

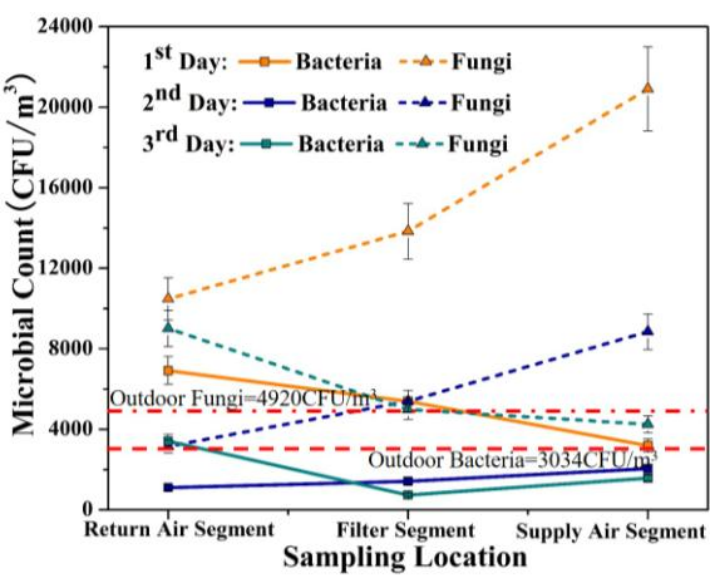

(b) K4 VAV system, 9:00 10:00

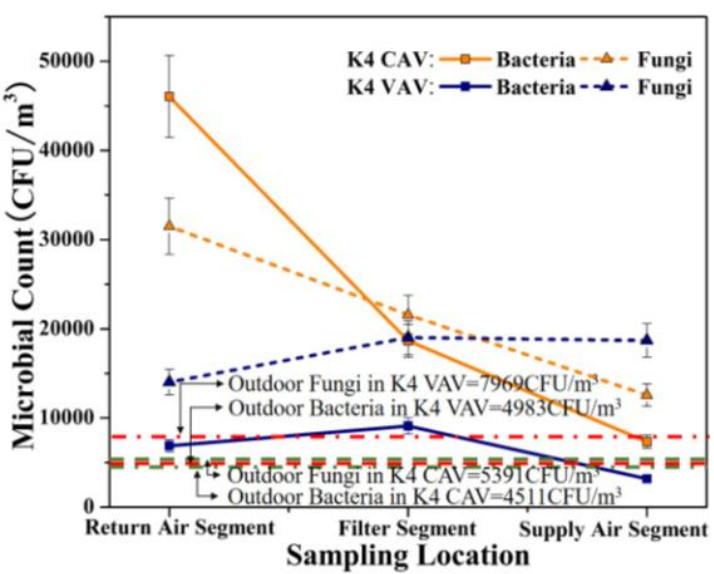

(d) K4 CAV/VAV system, 15:00 16:00

Fig. 4 Distribution of airborne microorganisms in different AHU systems.

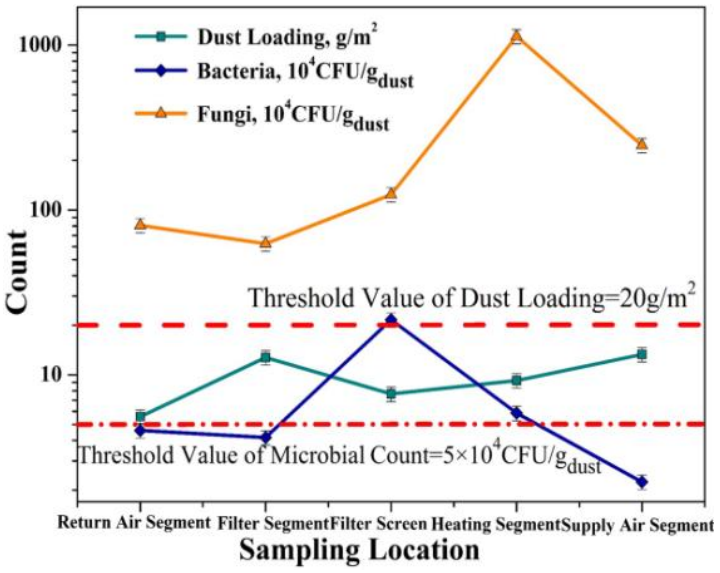

(a) K4 VAV system, 9:00 10:00

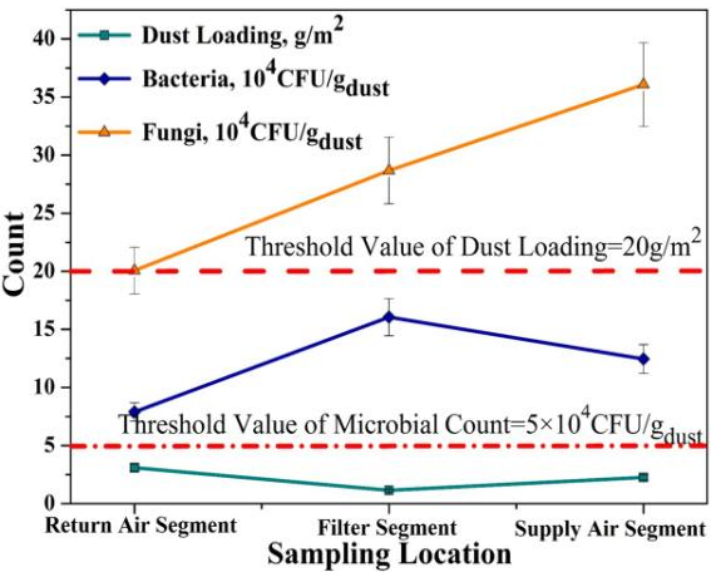

(b) K7 VAV system, 9:00 10:00

Fig. 5 Distribution of dust loading and dust-borne microorganisms in different systems. 


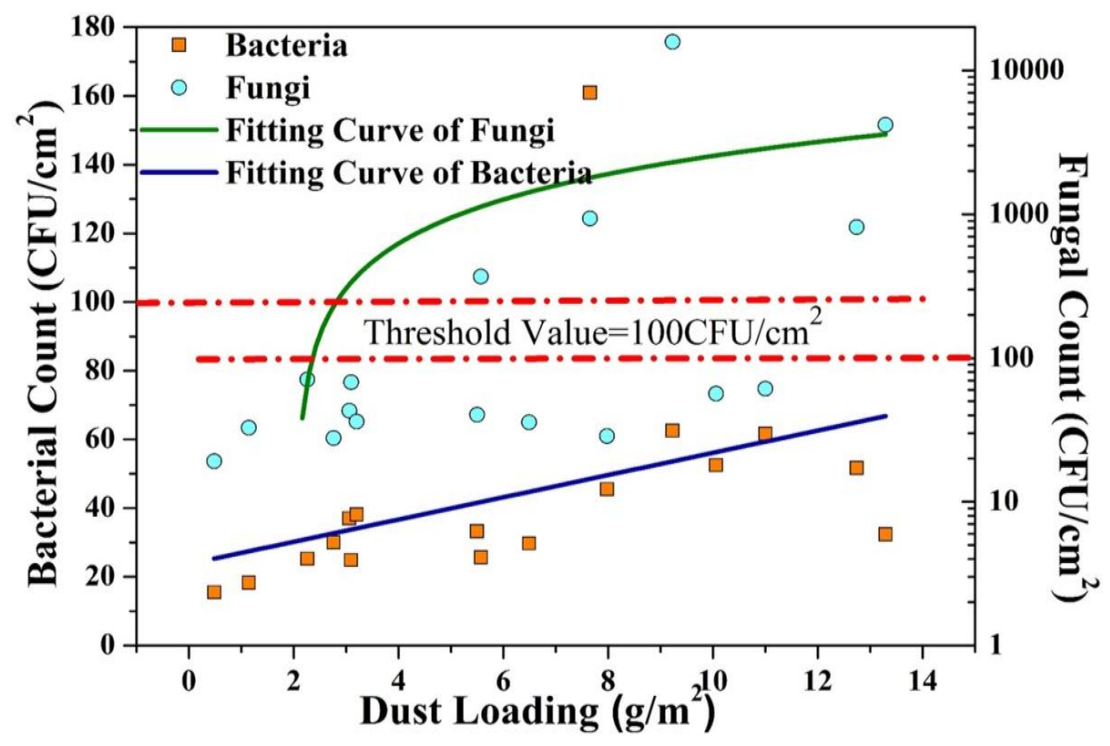

Fig. 6. Relationship between dust-borne microbial counts and dust loading in term of sampling

area.

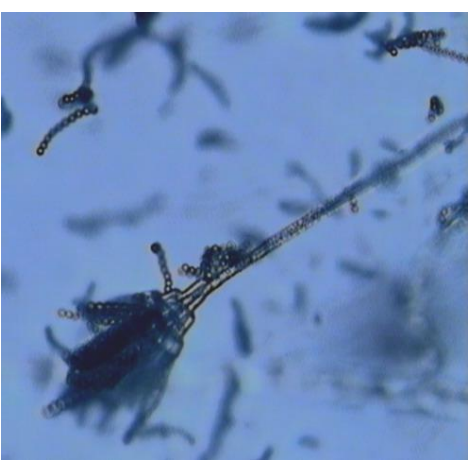

Penicillium

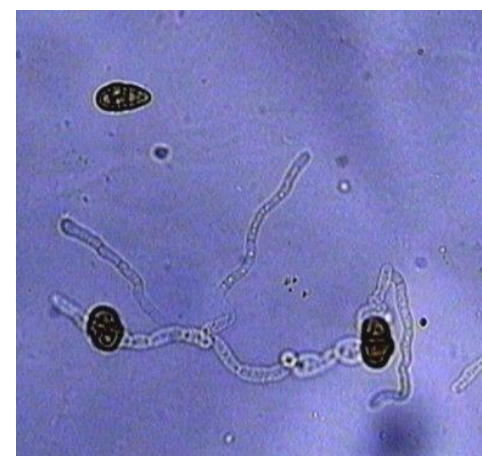

Alternaria

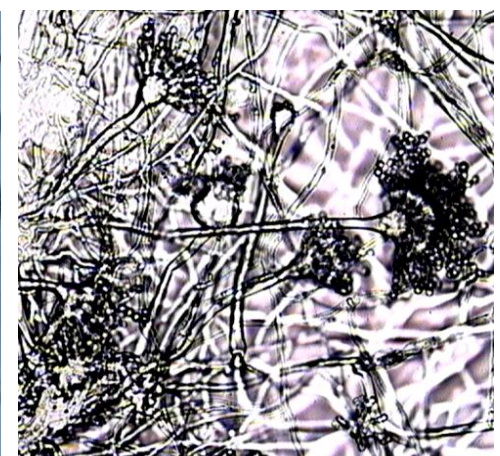

Aspergillus

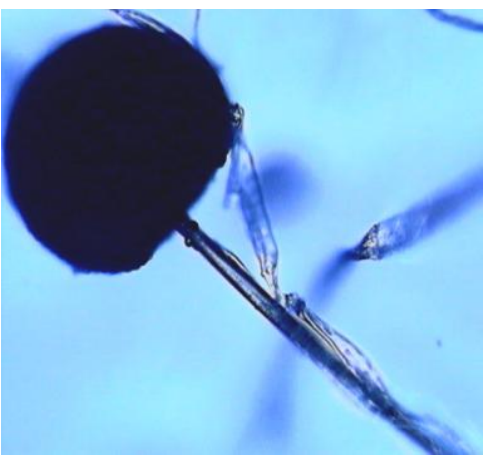

Mucor

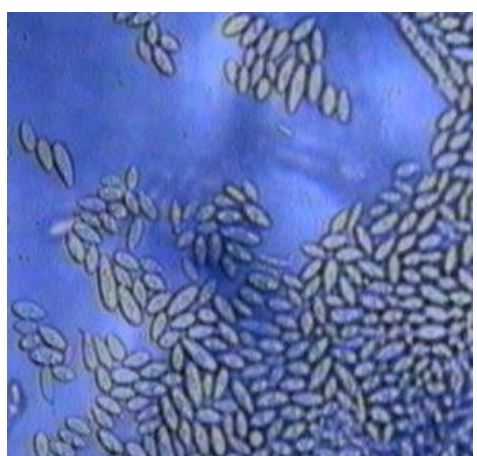

Cladosporium

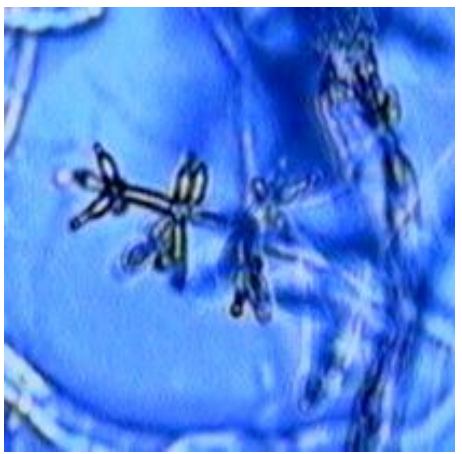

Trichoderma

Fig. 7. Morphological characteristics of six kinds of predominant fungi. 

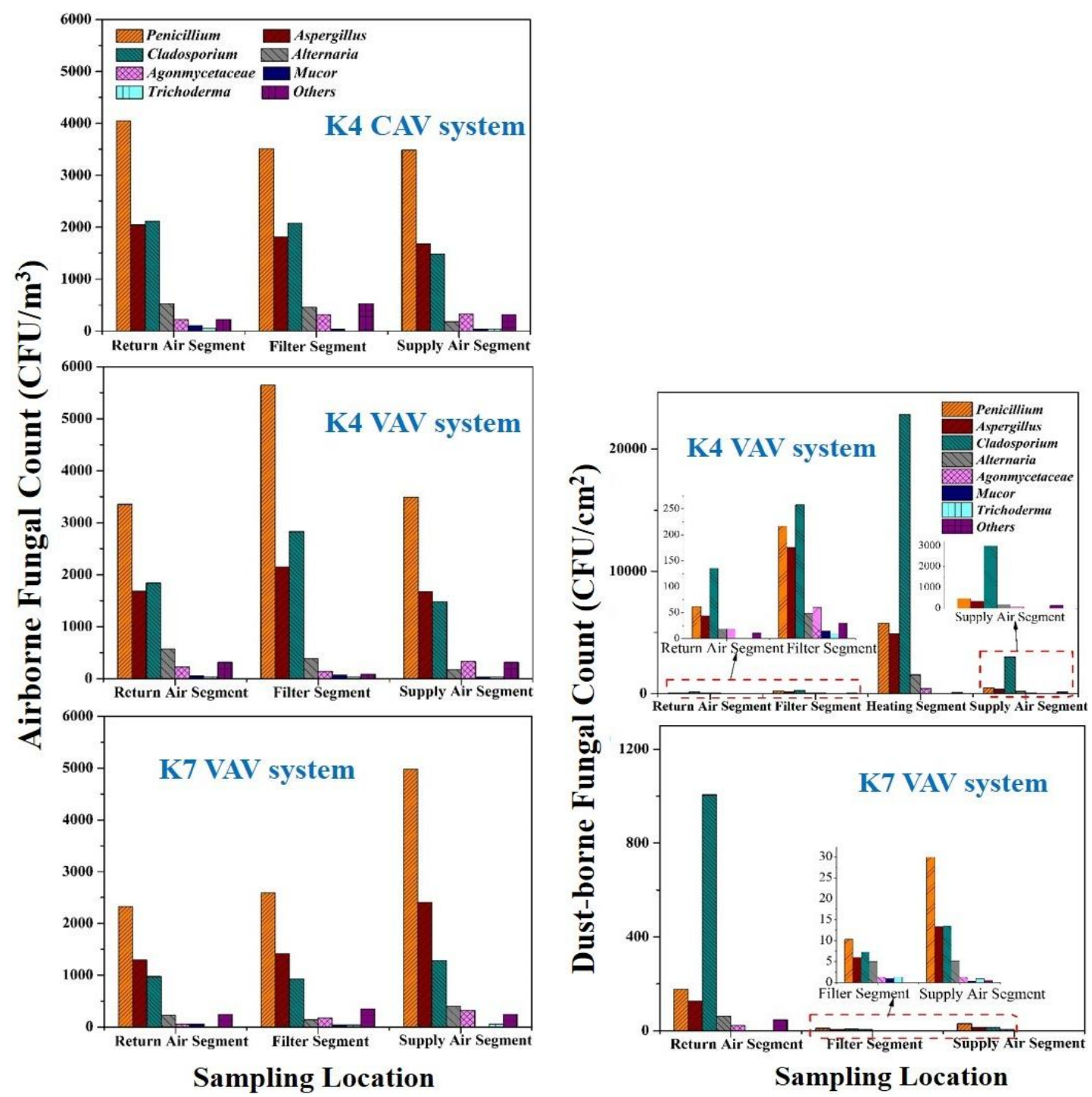

Fig. 8. Airborne and dust-borne fungi in AHU systems. 

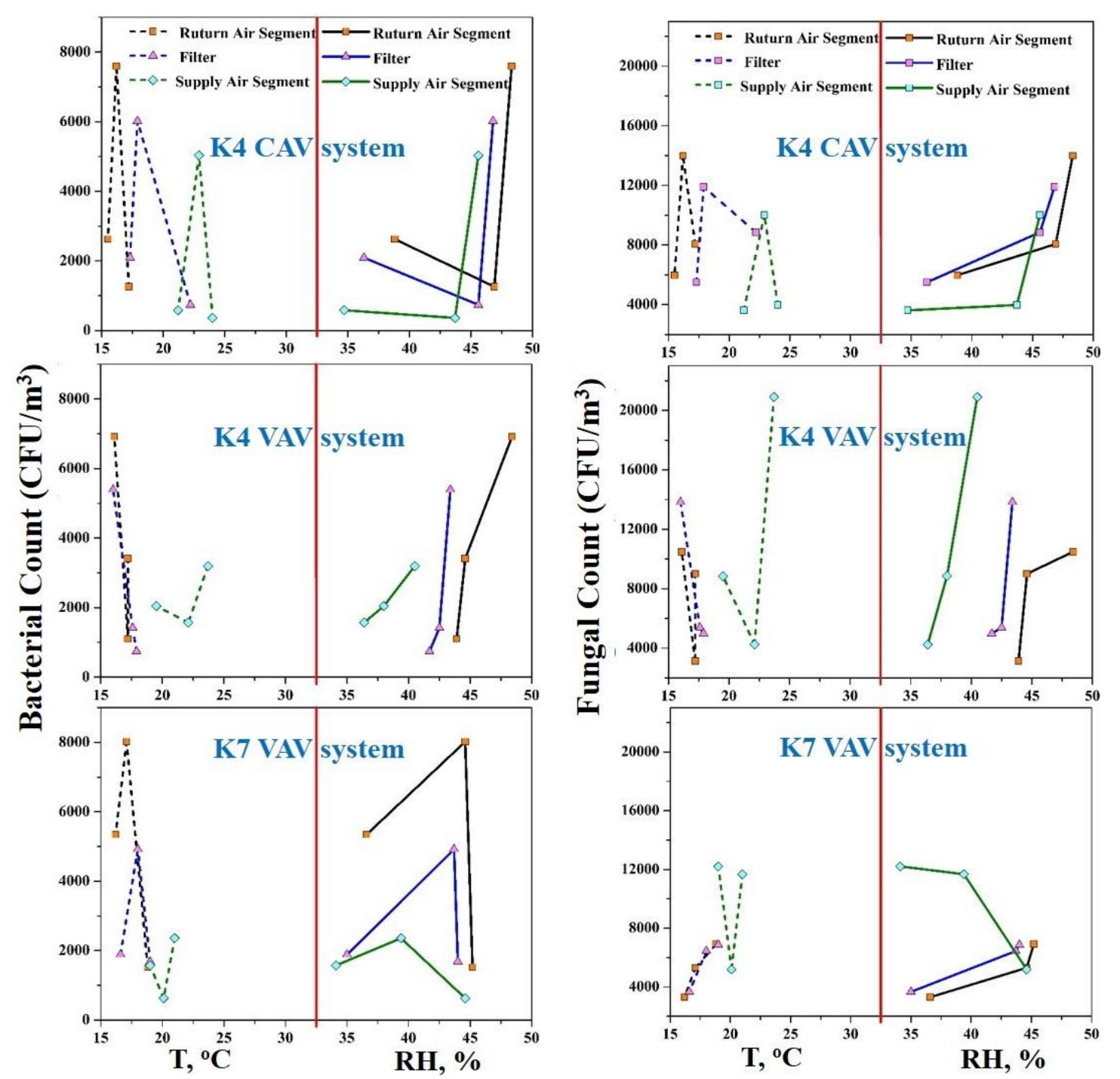

Fig. 9 Influence of temperature and RH to airborne microbial counts. 